\title{
EVALUATION OF IN-VITRO ACTIVITY OF AERIAL PART OF BARANJASIF (Achillea millefolium Linn.) EXTRACTS
}

\author{
Suheena Khanday ${ }^{1 *}$, Mohd. Afsahul Kalam², Ansar Ahmad², \\ Aamir Yousuf ${ }^{1}$, Sajad Salim ${ }^{1}$ and Younis Dar ${ }^{3}$ \\ ${ }^{1} \mathrm{MD}$ in IlmulAdvia at Regional Research Institute of Unani Medicine \\ Habak, Naseembagh Campus, Hazratbal, Kashmir University, Srinagar, J\&K, 190006 India \\ ${ }^{2}$ Department of Ilmul Advia, Regional Research Institute of Unani Medicine \\ Habak, Naseembagh Campus, Hazratbal, Kashmir University, Srinagar, J\&K, 190006 India \\ ${ }^{3}$ Research officer, Chemistry, Regional Research Institute of Unani Medicine \\ Habak, Naseembagh Campus, Hazratbal, Kashmir University, Srinagar, J\&K, 190006 India
}

\section{Research Paper}

Received: 20.05.2021

Revised: 27.05.2021

Accepted: 07.06.2021

\begin{abstract}
Hasah al-Kulya (renal calculi) is one of the leading problems affecting kidney. Recurrence of kidney stone formation is approximately $50 \%$, after 2-3 years of recovery. This makes the prevention of its recurrence an essential problem to address. Despite substantial progress in medical therapy, there is no drug with satisfactory effect. Furthermore, the drugs those are being used for its treatment have many side effects. Baranjasif (Achillea millefolium Linn.) is one of the drugs used in Unani Medicine that has been extensively used for the management of urolithiasis. The aim of this study is to evaluate the lithotriptic action of Baranjasif in-vitro. In this study, calcium oxalate stones were prepared experimentally followed by the preparation of semipermeable membrane by dissolving the outer shell of egg in $2 \mathrm{M} \mathrm{HCl}$ overnight. Calcium oxalate stones weighing $10 \mathrm{mg}$ were then allowed to react with 7 extracts of A. millefolium L. viz, Pet-ether, Chloroform, Ethyl Acetate, Methanol, Acetone, Hydro-alcohol and Aqueous by packing them together in semipermeable membrane. The reaction was performed on three different concentrations of each extract i.e., $50 \mathrm{mg}, 100 \mathrm{mg}$ and $150 \mathrm{mg}$. In addition to 7 groups, two more groups were taken, i) a negative group containing only the stone of weight $10 \mathrm{mg}$ and ii) standard group consisting of stone weighing $10 \mathrm{mg}$ and cystone (in concentrations of $50 \mathrm{mg}, 100 \mathrm{mg}$ and $150 \mathrm{mg}$ ). Statistical methods like mean standard deviation, percentage dissolution, percentage inhibition, $\mathrm{IC}_{50}$ and Pearson's correlation were applied to understand the extent of dissolution of stones in each group. The study advocates that Baranjasif reveals lithotriptic activity comparable to standard drug. The efficacy of the drug is directly proportional to its concentration. Ethyl acetate extract of the plant showed the most promising results.
\end{abstract}

No. of Pages: 10

References: 37

Keywords: Achillea millefolium L., Baranjasif, Kidney stone, In-Vitro, Unani Medicine, Hasah al-Kulya.

\section{INTRODUCTION}

Among urinary disorders, urolithiasis is the third most common prevalent disease involving the process of supersaturation, nucleation, aggregation and retention at the site of stone formation [1,2]. Its prevalence increases as age advances. As compared to women, it is common in men sharing a ratio of $1: 8[3,4,5]$. The solid accumulation of materials in kidneys results in renal stone formation whose size ranges from a grain to that of a golf ball. There are many types of renal stones. Most commonly kidney stones contain

*Corresponding author: suhinakhanday@gmail.com 
calcium in combination with either oxalate or phosphate constituting about $80 \%$ of kidney stones [6]. More than $60 \%$ of urolithiatic patients have calcium oxalate $(\mathrm{CaOx})$ stones [7]. Struvite stones constitute nearly 15\%, whereas uric acid and cysteine constitute $5-10 \%$ and $1-2 \%$ of renal stone disease respectively.

Management of urolithiasis include both medicinal as well as surgical procedures [8]. The conventional medicines to prevent hypercalciuria and hyperoxaluria induced kidney stones are thiazides diuretics and alkali citrate but scientific evidence for their effectiveness is less convincing [9]. On the other hand, removal procedures of kidney stones like surgery, Extracorporeal Shock Wave Lithotripsy (ESWL), Percutaneous Nephrostolithotomy (PCNL), etc. are expensive and as such everyone cannot afford it. Also, shock waves have traumatic effect and the residual stone fragments may persist even after the treatment which increases the chances of infection. In addition, ESWL causes hemorrhage, acute renal injury, decrease in renal function and hypertension [2].Despite the above facts, recurrence rate of stone formation is high and follow up for a couple of years is still needed [10].Efforts have been made to provide better alternatives of medical therapies and develop new agents which can be used either singly or in combination to prevent urolithiasis efficiently. In recent years, pronounced interest has been given towards the examination of drugs from plant products (phytotherapy) for the reasons of side effects of conventional drugs, inefficiency of synthetic conventional drugs, drug abuse etc. [11].

There are many systems of treatment available which are alternative to allopathic system (conventional medicine) such as traditional Chinese medicine, Ayurveda, Siddha, Homeopathic, Unani, etc. Unani system of medicine has holistic approach of treatment, i.e., instead of treating the symptoms, the whole body is treated. Since these drugs have relatively lesser side effects, people nowadays find herbal medicine more reliable than conventional. Therefore scientific validation of herbal medicine is the need of the hour. For the treatment of renal calculi there are a number of single drugs, e.g. Aalubalu (Prunus persica), Duqu (Peucedanum grande), Beekh-i-Nil (Ipomea purga root), Hajrul Yahood (Lapis judaicus), Khar-i-Khasak (Tribulus terrestris), Kitmi (Althea officinalis), Nawshadar, etc. as well as compound drugs e.g. Banadiq-ul-Buzoor, Jawarish Zarooni, Ma'jun Aqrab, Ma'jun Hajrul Yahood, etc. used in Unani system of medicine [12,13,14].

Achillea millefolium Linn. is one of the important medicinal plant which is used as lithotriptic drug in Unani system of Medicine [12,15]. Achillea millefolium Linn. belongs to the family Asteraceae [16] and is a widely distributed specie. Although it is native to Western Asia and Europe but is also found abundantly in most temperate regions including North
America [17].It is also found in western Himalaya, from Kashmir to Kumaon, 6000-9000 ft above sea level [18].In addition to Mufattit-i-Hasāt (lithotriptic) property, this drug has also been claimed to possesses the properties of Mudirr-iBawl (diuretic), Mufattih (deobstruent), Muhallil (antiinflammatory), Mulattif (demulcent), Mudirr-i-hayd (Emmenagogue), Mukhrij-i-Janīn (Abortifacient), Musakhkhin (calorific), Dafi' Hummā (antipyretic) etc. $[12,15,19,20,21]$.

Achillea millefolium Linn. has also been used for the treatment of diseases like high blood pressure, hemorrhoids, bruises, menstrual disorder, malaria, hepatitis, jaundice, headache, cough, influenza, as hepatoprotective etc. [22].Many studies have been done to illustrate and verify that A. millefolium Linn. possesses pharmacological activities like anti-inflammatory, antioxidant, antifungal, antitumor, antiseptic, spasmolytic, hemostatic, cholagogue, hepatoprotective effects which are due to the various chemical constituents present in it viz., Sesquiterpene, phenolic compounds and essential oils [23,24,25,26,27,28]. The most active part of the plant is its flowering tops which contain the essential oil and are used chiefly for the treatment of hemorrhage, diarrhea, influenza, dysmenorrhea and as a haemostatic [29, 30].

\section{MATERIALS AND METHODS}

\section{Plant Material Collection}

The study was carried out at department of Ilmul Advia, Regional Research Institute of Unani Medicine (RRIUM) Srinagar, deptt. of Pharmaceutical Science and Department of Chemistry in Kashmir University. The fresh plant Achillea millefolium Linn. was collected in July, 2018 at an altitude of 2,740 m from Pahalgam, Anantnag, Kashmir. The plant was identified and authenticated by Dr. Akhtar H. Malik, Centre for Biodiversity and Taxonomy, University of Kashmir and submitted the specimen in KASH herbarium under Specimen Voucher no. 2700-(KASH), Department of Botany, University of Kashmir.

\section{Evaluation for Anti-urolithiatic Activity:}

Step I- Preparation of experimental kidney stones (calcium oxalate stones) by homogenous preparation:

Calcium oxalate stone was chosen to observe the dissolution, for the reason that $80 \%$ of kidney stones are calcium stones which include calcium oxalate stones and calcium phosphate stones with calcium oxalate stones constituting $60 \%$ of calcium stones. Furthermore, in industrial areas about $70 \%$ of urinary stones are calcium oxalate stones [31]. The stones used in this study were prepared in the laboratory as follows:

First of all $2 \mathrm{~N}$ sulphuric acid $\left(\mathrm{H}_{2} \mathrm{SO}_{4}\right)$ was prepared by adding $5.5 \mathrm{ml}$ of $\mathrm{H}_{2} \mathrm{SO}_{4}$ in $94.5 \mathrm{ml}$ of distilled water. After that, $1.47 \mathrm{~g}$ of calcium chloride dihydrate was dissolved in $100 \mathrm{ml}$ of 
distilled water and $1.34 \mathrm{~g}$ of sodium oxalate was dissolved in $100 \mathrm{ml}$ of $2 \mathrm{~N} \mathrm{H}_{2} \mathrm{SO}_{4}$ to make an equimolar solution. The so obtained equimolar solution of calcium chloride dihydrate in distilled water and sodium oxalate in $2 \mathrm{~N} \mathrm{H}_{2} \mathrm{SO}_{4}$ were allowed to react in a beaker to precipitate out calcium oxalate with stirring. Precipitates were freed from traces of $\mathrm{H}_{2} \mathrm{SO}_{4}$ by ammonia solution. The precipitates were washed with distilled water and dried at $60^{\circ} \mathrm{C}$ for 4 hours [32]. Fig. 1 (a) shows the photograph of experimentally prepared calcium oxalate stones used in this study.
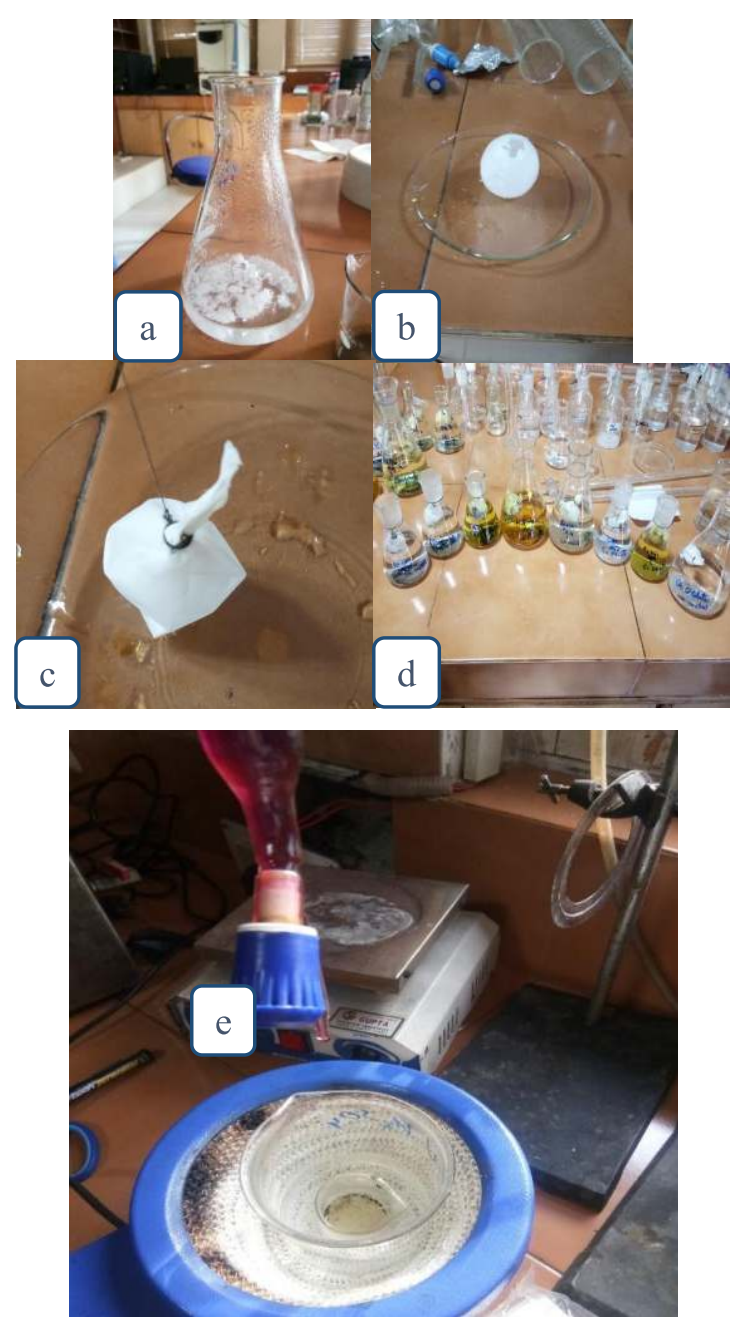

Fig. 01: Photograph showing (a) experimentally formed calcium oxalate stones, (b) experimentally formed egg semipermeable membrane, (c) Sutured egg semipermeable membrane, (d) Stone and extracts in tris buffer (e) Titration Process

Step II-Preparation of semi-permeable membrane from farm eggs:

The semi-permeable membrane of egg lies in between the outer calcified shell and the inner contentsviz: albumin and yolk. Apexes of eggs were punctured by a glass rod in order to squeeze out the entire content. Empty eggs were washed thoroughly with distilled water and placed in a beaker containing $2 \mathrm{M}$ Hydrochloric acid ( $\mathrm{HCl}$ ) for overnight, causing complete decalcification. Subsequently, the content was washed with distilled water, placed in ammonia solution for neutralization of acid traces in the moistened condition for a while and rinsed with distilled water and stored in refrigerator at a pH of 7-7.4 [32]. Fig. 1 (b) shows experimentally formed egg semi-permeable membrane.

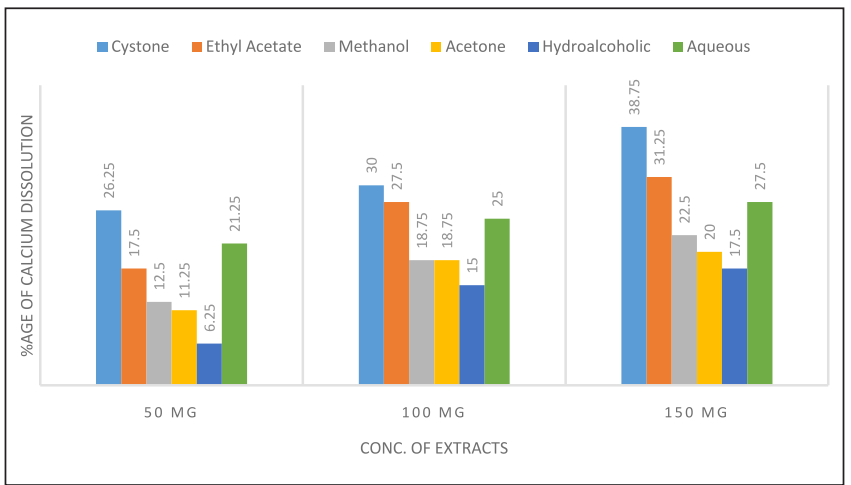

Fig. 2. Graphical representation of dissolution of calcium oxalate stone by various extracts of $A$. millefolium Linn

Step III- Estimation of calcium oxalate by Titrimetry: The procedure for estimation of calcium oxalate in this study has been adopted from Jha, et al., 2016 and Saravana Singh et al, 2016 with slight modifications [33,34]. The dissolution percentage of calcium oxalate was evaluated by taking exactly $10 \mathrm{mg}$ of calcium oxalate and 50,100,150 mg of the extracts packed together in the semipermeable membrane of egg by suturing. The contents were allowed to suspend in a conical flask containing $100 \mathrm{ml}$ of $0.1 \mathrm{M}$ Tris buffer $(0.1 \mathrm{M}$ of tris buffer was prepared by adding $12.1 \mathrm{gm}$ of tris buffer in $1000 \mathrm{ml}$ of distilled water). Several groups of extracts corresponding to different concentrations of drugs were formed as shown in table 1. In addition to that two more groups, one serving as blank, containing only $10 \mathrm{mg}$ of calcium oxalate and the other as positive control, containing $10 \mathrm{mg}$ of calcium oxalate mixed with different concentrations of standard drug Cystone were formed. The incubator was preheated at $37^{\circ} \mathrm{C}$ for 2 hours and all the groups were placed in the incubator at $37^{\circ} \mathrm{C}$ for $7-8$ hours. The contents of each semi-permeable membrane were removed into test tubes. $2 \mathrm{ml}$ of $1 \mathrm{~N} \mathrm{H}_{2} \mathrm{SO}_{4}$ was then added in each test tube. The contents of test tubes were then titrated with $0.01 \mathrm{~N}$ Potassium permanganate $\left(\mathrm{KMnO}_{4}\right)$ till a light pink color (end

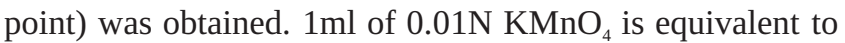
$1.25 \mathrm{mg}$ of calcium oxalate. Fig 01. (c)shows the photographs of sutured egg semi-permeable membrane, (d) beakers containing extracts of Achillea millefolium Linn. along with calcium oxalate stones and (e) titration process. 
Table 1: Percentage of dissolution of calcium oxalate stone (10 mg) by various extracts of Achillea millefolium Linn.

\begin{tabular}{|c|c|c|c|c|c|c|c|}
\hline S. No. & Group & $\begin{array}{c}\text { Concentration } \\
\text { of drug (in } \mathrm{mg} \text { ) }\end{array}$ & $\begin{array}{c}\text { Vol. of } \\
\text { standard } \mathrm{KMnO}_{4}\end{array}$ & $\begin{array}{l}\text { Wt. of Calcium } \\
\text { estimated }\end{array}$ & $\begin{array}{l}\text { Wt. of } \\
\text { Calcium } \\
\text { reduced }\end{array}$ & $\begin{array}{l}\text { Percentage of } \\
\text { Dissolution }\end{array}$ & $\begin{array}{l}\text { Percentage of } \\
\text { Inhibition }\end{array}$ \\
\hline 1. & $\begin{array}{l}\text { Group I } \\
\text { (Negative control) }\end{array}$ & - & $8 \mathrm{ml}$ & $10 \mathrm{mg}$ & - & - & $100 \%$ \\
\hline \multirow[t]{3}{*}{2.} & \multirow{3}{*}{$\begin{array}{l}\text { Group II (Standard, } \\
\text { containing cystone) }\end{array}$} & 50 & $5.9 \mathrm{ml}$ & 7.375 & 2.625 & $26.25 \%$ & $73.75 \%$ \\
\hline & & 100 & $5.6 \mathrm{ml}$ & 7.00 & 3.00 & $30 \%$ & $70 \%$ \\
\hline & & 150 & $4.9 \mathrm{ml}$ & 6.125 & 3.875 & $38.75 \%$ & $61.25 \%$ \\
\hline 3. & $\begin{array}{l}\text { Group III } \\
\text { (containing Pet-ether } \\
\text { extract) }\end{array}$ & 50 & $8 \mathrm{ml}$ & 10 & - & - & $100 \%$ \\
\hline \multirow{5}{*}{4.} & \multirow{5}{*}{$\begin{array}{l}\text { Group IV } \\
\text { (containing } \\
\text { Chloroform extract) }\end{array}$} & 100 & $8 \mathrm{ml}$ & 10 & - & - & $100 \%$ \\
\hline & & 150 & $8 \mathrm{ml}$ & 10 & - & - & $100 \%$ \\
\hline & & 50 & $8 \mathrm{ml}$ & 10 & - & - & $100 \%$ \\
\hline & & 100 & $8 \mathrm{ml}$ & 10 & - & - & $100 \%$ \\
\hline & & 150 & $8 \mathrm{ml}$ & 10 & - & - & $100 \%$ \\
\hline \multirow[t]{3}{*}{5} & \multirow{3}{*}{$\begin{array}{l}\text { Group V (containing } \\
\text { Ethyl-acetate extract) }\end{array}$} & 50 & $6.6 \mathrm{ml}$ & 8.25 & 1.75 & $17.5 \%$ & $82.5 \%$ \\
\hline & & 100 & $5.8 \mathrm{ml}$ & 7.25 & 2.75 & $27.5 \%$ & $72.5 \%$ \\
\hline & & 150 & $5.5 \mathrm{ml}$ & 6.875 & 3.125 & $31.25 \%$ & $68.75 \%$ \\
\hline \multirow[t]{3}{*}{6} & \multirow{3}{*}{$\begin{array}{l}\text { Group VI } \\
\text { (containing Methanol } \\
\text { extract) }\end{array}$} & 50 & $7 \mathrm{ml}$ & 8.75 & 1.25 & $12.5 \%$ & $87.5 \%$ \\
\hline & & 100 & $6.5 \mathrm{ml}$ & 8.125 & 1.875 & $18.75 \%$ & $81.25 \%$ \\
\hline & & 150 & $6.2 \mathrm{ml}$ & 7.75 & 2.25 & $22.5 \%$ & $77.5 \%$ \\
\hline \multirow[t]{3}{*}{7} & \multirow{3}{*}{$\begin{array}{l}\text { Group VII } \\
\text { (containing Acetone } \\
\text { extract) }\end{array}$} & 50 & $7.1 \mathrm{ml}$ & 8.875 & 1.125 & $11.25 \%$ & $88.75 \%$ \\
\hline & & 100 & $6.5 \mathrm{ml}$ & 8.125 & 1.875 & $18.75 \%$ & $81.25 \%$ \\
\hline & & 150 & $6.4 \mathrm{ml}$ & 8.00 & 2.00 & $20 \%$ & $80 \%$ \\
\hline \multirow[t]{3}{*}{8} & \multirow{3}{*}{$\begin{array}{l}\text { Group VIII } \\
\text { (containing Hydro- } \\
\text { alcohol extract) }\end{array}$} & 50 & $7.5 \mathrm{ml}$ & 9.375 & 0.625 & $6.25 \%$ & $93.75 \%$ \\
\hline & & 100 & $6.8 \mathrm{ml}$ & 8.50 & 1.5 & $15 \%$ & $85 \%$ \\
\hline & & 150 & $6.6 \mathrm{ml}$ & 8.25 & 1.75 & $17.5 \%$ & $82.5 \%$ \\
\hline \multirow[t]{3}{*}{9} & \multirow{3}{*}{$\begin{array}{l}\text { Group IX } \\
\text { (containing Aqueous } \\
\text { extract) }\end{array}$} & 50 & $6.3 \mathrm{ml}$ & 7.875 & 2.125 & $21.25 \%$ & $78.75 \%$ \\
\hline & & 100 & $6 \mathrm{ml}$ & 7.5 & 2.5 & $25 \%$ & $75 \%$ \\
\hline & & 150 & $5.8 \mathrm{ml}$ & 7.25 & 2.75 & $27.5 \%$ & $72.5 \%$ \\
\hline
\end{tabular}

To know the quantity of calcium oxalate the test substance could dissolve, the amount of undissolved calcium oxalate was subtracted from the total quantity used in the experiment in the beginning.

The percentage dissolution of calcium oxalate stone (10 mg) in various extracts of Achillea millefolium Linn was observed. The statistical analysis was carried out by calculating percentage inhibition, mean standard deviation of various trials, half maximal inhibitory concentration $\left(\mathrm{IC}_{50}\right)$, and Pearson's correlation among the extracts.

\section{RESULTS AND DISCUSSIONS}

Kidney stones occurs due to supersaturation of urine with the 
Table 2: Descriptive statistics for individual extracts with concentrations.

\begin{tabular}{|c|c|c|c|c|c|c|}
\hline \multirow{4}{*}{$\begin{array}{l}\text { Group II } \\
\text { (Standard containing } \\
\text { cystone) }\end{array}$} & $\begin{array}{l}\text { Concentration } \\
\text { of drug (mg) }\end{array}$ & $\mathbf{N}$ & Mean $\% \pm S D$ & Min & Max & $\mathrm{IC}_{50}$ \\
\hline & 50 & 3 & $26.25 \pm 0.31$ & 26.1 & 26.75 & \multirow{3}{*}{237} \\
\hline & 100 & 3 & $30 \pm 2.3$ & 27.33 & 31.22 & \\
\hline & 150 & 3 & $38.75 \pm 1.9$ & 37.55 & 39.33 & \\
\hline \multirow{3}{*}{$\begin{array}{l}\text { Group III } \\
\text { (Pet-ether extract) }\end{array}$} & 50 & 3 & - & - & - & \\
\hline & 100 & 3 & - & - & - & \\
\hline & 150 & 3 & - & - & - & \\
\hline \multirow{3}{*}{$\begin{array}{l}\text { Group IV } \\
\text { (Containing } \\
\text { Choloform extract) }\end{array}$} & 50 & 3 & - & - & - & \\
\hline & 100 & 3 & - & - & - & \\
\hline & 150 & 3 & - & - & - & \\
\hline \multirow{3}{*}{$\begin{array}{l}\text { Group V (Containing } \\
\text { Ethyl-acetate extract) }\end{array}$} & 50 & 3 & $17.5 \pm 0.8$ & 16.15 & 18.33 & \multirow{3}{*}{274} \\
\hline & 100 & 3 & $27.51 \pm 1.7$ & 25.31 & 29.3 & \\
\hline & 150 & 3 & $31.25 \pm 1.3$ & 28.3 & 32.6 & \\
\hline \multirow{3}{*}{$\begin{array}{l}\text { Group VI (Containing } \\
\text { Methnol extract) }\end{array}$} & 50 & 3 & $12.5 \pm 0.8$ & 11.05 & 13.33 & \multirow{3}{*}{421} \\
\hline & 100 & 3 & $18.75 \pm 1.7$ & 16.11 & 20.31 & \\
\hline & 150 & 3 & $22.50 \pm 1.3$ & 21.31 & 23.6 & \\
\hline \multirow{3}{*}{$\begin{array}{l}\text { Group VII (Containing } \\
\text { Acetone extract) }\end{array}$} & 50 & 3 & $11.25 \pm 2.3$ & 9.05 & 12.33 & \multirow{3}{*}{467} \\
\hline & 100 & 3 & $18.75 \pm 0.9$ & 17.11 & 21.31 & \\
\hline & 150 & 3 & $20 \pm 0.10$ & 19.31 & 23.65 & \\
\hline \multirow{3}{*}{$\begin{array}{l}\text { Group VIII (Containing } \\
\text { hydro Alcohol extract) }\end{array}$} & 50 & 3 & $6.25 \pm 3.3$ & 4.05 & 10.33 & \multirow{3}{*}{439} \\
\hline & 100 & 3 & $15 \pm 1.9$ & 13.11 & 18.01 & \\
\hline & 150 & 3 & $17.5 \pm 0.80$ & 16.21 & 18.65 & \\
\hline \multirow{3}{*}{$\begin{array}{l}\text { Group IX } \\
\text { (Aqueous) }\end{array}$} & 50 & 3 & $21.25 \pm 2.3$ & 19.05 & 22.32 & \multirow{3}{*}{528} \\
\hline & 100 & 3 & $25 \pm 2.9$ & 23.33 & 26.65 & \\
\hline & 150 & 3 & $27.5 \pm 0.10$ & 26.21 & 28.01 & \\
\hline
\end{tabular}

substances occurring in it as a result of which these substances crystallize to form stones. There are many factors associated with the occurrence of renal calculi like dietary habits, climate geographical area, age, gender, drugs etc. [35].

In classical text books of Unani System of Medicine, management of urinary stone has been discussed by many renowned Unani physicians in a systematic way. For treatment of renal calculi, they recommended 1) Ilaj BilGhiza (dietotherapy);2) Ilaj Bit-Tadbeer (regimental therapy) 3); Ilaj Bid-Dawa(pharmacotherapy) and 4) Ilaj bilYad (surgery). In Dietotherapy i.e. Ilaj Bil-Ghiza, foods which are soft, easy to digest and produce good chyme are allowed to eat. In addition, plenty of fluid is advised. Foods containing high content of oxalates, hard to digest and those which produce morbid matters, are avoided. Ilaj Bit-Tadbeer (regimental therapy) has two main aims, Talteef-i-Madda (softening of morbid matter) and Taqti'-i-Madda (refining)for which patient is given emetic or purgatives drugs or diuretics. Fasd (Venesection) can also be done on Basilic vein (Rag-i-Basaleeq). Other regimental therapies include Huqna (Enema), Abzan (Sitz bath) etc. Ilaj Bid-Dawa (pharmacotherapy) follows the principle to breakdown the stone and its expulsion which is illustrated as Tafteet- $i$ Hasatand Idrar-i-Bawl respectively. If the patient is not relieved by the above line of treatment then, this is followed by surgical procedures [36,37,12].

In classical text books of Unani Medicine, it has been mentioned that lithotriptic drugs must possess mild degree of heat as severe degree of heat makes the substance harder. Ibn- 
Table 3: Correlation between extract and concentrations used in the study.

\begin{tabular}{|c|c|c|c|c|c|c|c|}
\hline \multicolumn{8}{|c|}{ Correlations } \\
\hline & & Cystone & $\begin{array}{c}\text { Ethyl-Acetate } \\
\text { Extract }\end{array}$ & $\begin{array}{l}\text { Methnol } \\
\text { Extrac }\end{array}$ & $\begin{array}{l}\text { Acetone } \\
\text { Extract }\end{array}$ & $\begin{array}{l}\text { Alcohol } \\
\text { Extract }\end{array}$ & Aqueous \\
\hline \multirow{3}{*}{ Cystone } & \multirow{3}{*}{$\begin{array}{l}\text { Pearson } \\
\text { Correlation } \\
\text { Sig. (2-tailed) } \\
\mathrm{N}\end{array}$} & 1 & $.852 * *$ & $.924 * *$ & $.804 * *$ & $.795^{*}$ & $.875^{* *}$ \\
\hline & & & .004 & .000 & .009 & .010 & .002 \\
\hline & & 9 & 9 & 9 & 9 & 9 & 9 \\
\hline \multirow{3}{*}{$\begin{array}{l}\text { Ethyl-Acetate } \\
\text { Extract }\end{array}$} & \multirow{3}{*}{$\begin{array}{l}\text { Pearson } \\
\text { Correlation } \\
\text { Sig. (2-tailed) } \\
\mathrm{N}\end{array}$} & $.852 * *$ & 1 & $.982 * *$ & $.984 * *$ & $.968 * *$ & $.969 * *$ \\
\hline & & .004 & .000 & .000 & .000 & .000 & \\
\hline & & 9 & 9 & 9 & 9 & 9 & 9 \\
\hline \multirow{3}{*}{$\begin{array}{l}\text { Methnol } \\
\text { Extract }\end{array}$} & \multirow{3}{*}{$\begin{array}{l}\text { Pearson } \\
\text { Correlation } \\
\text { Sig. (2-tailed) } \\
\mathrm{N}\end{array}$} & $.924 * *$ & $.982 * *$ & 1 & $.965^{* *}$ & $.958 * *$ & $.984 * *$ \\
\hline & & .000 & .000 & & .000 & .000 & .000 \\
\hline & & 9 & 9 & 9 & 9 & 9 & 9 \\
\hline \multirow{3}{*}{$\begin{array}{l}\text { Acetone } \\
\text { Extract }\end{array}$} & \multirow{3}{*}{$\begin{array}{l}\text { Pearson } \\
\text { Correlation } \\
\text { Sig. (2-tailed) } \\
\mathrm{N}\end{array}$} & $.804 * *$ & $.984 * *$ & $.965 * *$ & 1 & $.978^{* *}$ & $.969 * *$ \\
\hline & & .009 & .000 & .000 & & .000 & .000 \\
\hline & & 9 & 9 & 9 & 9 & 9 & 9 \\
\hline \multirow{3}{*}{$\begin{array}{l}\text { Alcohol } \\
\text { Extract }\end{array}$} & \multirow{3}{*}{$\begin{array}{l}\text { Pearson } \\
\text { Correlation } \\
\text { Sig. (2-tailed) } \\
\mathrm{N}\end{array}$} & $.795^{*}$ & $.968 * *$ & $.958 * *$ & $.978 * *$ & 1 & $.980 * *$ \\
\hline & & .010 & .000 & .000 & .000 & & .000 \\
\hline & & 9 & 9 & 9 & 9 & 9 & 9 \\
\hline \multirow{3}{*}{ Aqueous } & \multirow{3}{*}{$\begin{array}{l}\text { Pearson } \\
\text { Correlation } \\
\text { Sig. (2-tailed) } \\
\mathrm{N}\end{array}$} & $.875^{* *}$ & $.969 * *$ & $.984 * *$ & $.969 * *$ & $.980 * *$ & 1 \\
\hline & & .002 & .000 & .000 & .000 & .000 & \\
\hline & & 9 & 9 & 9 & 9 & 9 & 9 \\
\hline \multicolumn{8}{|c|}{ **. Correlation is significant at the 0.01 level (2-tailed). } \\
\hline & & *. Correl & ion is significan & $\mathrm{t}$ the $0.05 \mathrm{l}$ & (2-tailed). & & \\
\hline
\end{tabular}

Sina has mentioned that for the treatment of renal calculi, compound drug must possess both lithotriptic and diuretic property. The reason behind it is that lithotriptic action of drug breaks down the stone while its diuretic action causes excessive diuresis and helps the fragments to pass out through urine [12].

Achillea millefolium Linn. is one among those drugs possessing temperament of mild heat. It possesses property of lithotriptic and diuretic action which fulfills the quality of lithotriptic drugs as said by Ibn-Sina. It has been used by Unani physicians since a long period. It is used alone or in combination with other drugs either orally, or locally as sitz bath, enema etc. Baranjasif also possesses anti-microbial characteristics which may play an additional role in prevention of formation of secondary stones caused by infections in urine. Many scientific studies have been carried out on this plant e.g. antimicrobial activity, estrogenic activity, choleretic activity, antioxidant activity etc. But its lithotriptic action has not been proven scientifically yet. Therefore, this study was taken up to provide experimental evidence for the claim made by Unani physicians about the efficacy of Achillea millefolium Linn. in the treatment of urolithiasis. 


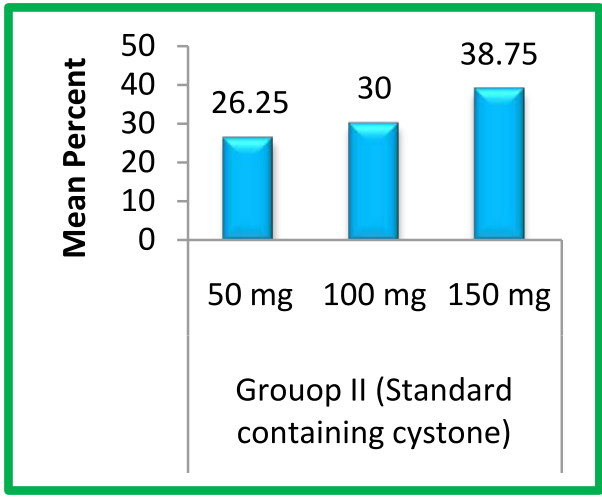

(a)

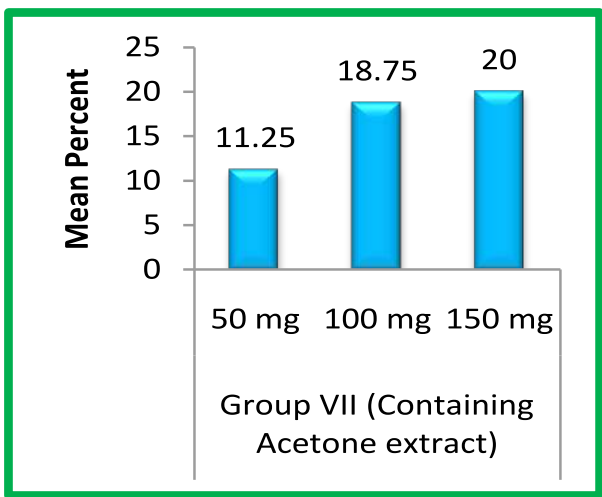

(d)

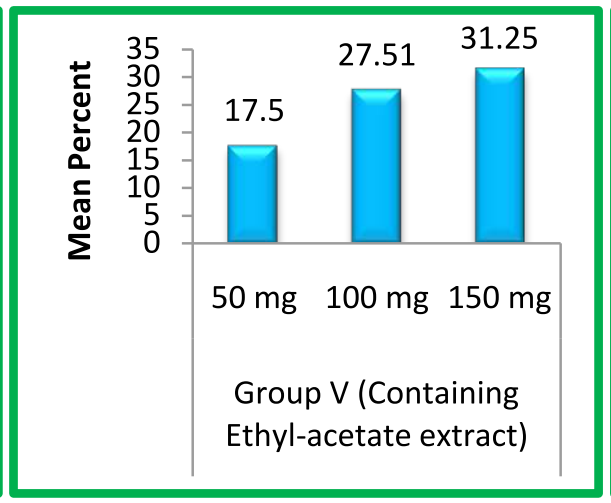

(b)

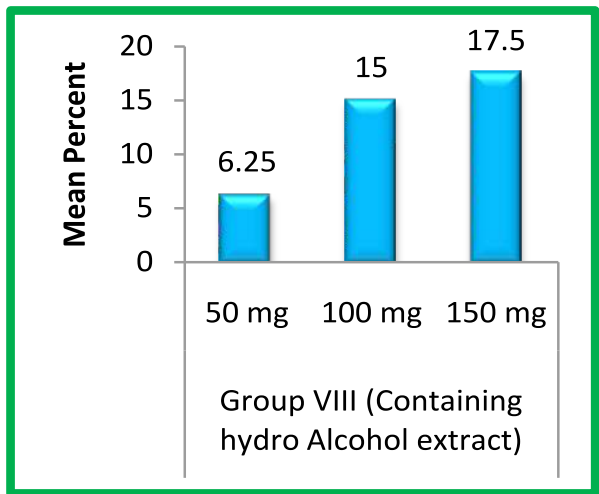

(e)

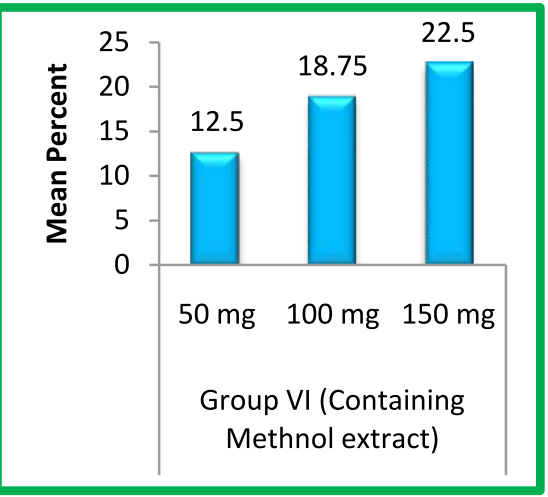

(c)

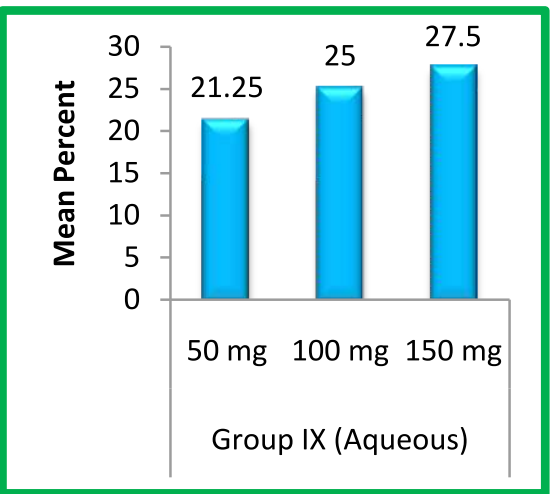

(f)

Fig. 3: Mean percent dissolution of calcium oxalate stone in: (a) cystone, (b) ethyl-acetate extract, (c) Methanol extract, (d) Acetone extract, (e) hydro alcohol extract and (f) Aqueous extract.

Various extracts of aerial part of the plant was studied for its lithotriptic activity.

The percentage dissolution of calcium oxalate stone (10 mg) in various extracts of Achillea millefolium Linn is shown in table 1and fig. 2 and 3. The statistical analysis was carried out by calculating percentage inhibition as given in table 1 , mean standard deviation of various trials, half maximal inhibitory concentration $\left(\mathrm{IC}_{50}\right)$, given in table 2 and Pearson's correlation among the extracts (table 3).

The standard group showed significant dissolution rate of $26.25 \%, 30 \%$ and $38.75 \%$ at the concentrations of $50 \mathrm{mg}, 100$ $\mathrm{mg}$ and $150 \mathrm{mg}$ respectively. Ethyl acetate extract of Achillea millefolium Linn. on the other hand, showed comparable results with dissolution rates of $17.5 \%, 27.50 \%$ and 31.25 at the concentrations of $50 \mathrm{mg}, 100 \mathrm{mg}$ and $150 \mathrm{mg}$ respectively. The dissolution rates of aqueous extract were $21.25 \%, 25 \%, 27.5 \%$ at the concentrations of $50 \mathrm{mg}, 100 \mathrm{mg}$ and $150 \mathrm{mg}$ respectively. The dissolution rates of methanol extract were $12.5 \%$. $18.75 \%, 22.5 \%$ at the corresponding concentrations respectively. Aqueous extract was found to possess better dissolution rate than the methanol extract of the plant. Acetone extract showed lesser rates of dissolution comparatively with the dissolution rates of $11.25 \%, 18.75 \%$ and $20 \%$ and the least activity was found in Hydro-alcohol extract with the dissolution rates of $6.25 \%, 15$ and $17.5 \%$ at the corresponding concentrations respectively. No activity was seen in pet-ether and chloroform extract implying the inefficiency of these groups in treatment of the disease caused due to the calcium oxalate kidney stones. This indicates that the mean percentage dissolution of calcium oxalate is maximum in standard drug as compared to the rest of the extracts of Achillea millefolium Linn. However, ethyl acetate extract of the plant also shows the comparable degree of dissolution.

Furthermore, it is evident from the figure 4 that the mean percentage dissolution of calcium oxalate tends to increase with increase in the concentration of extracts. In order to get a clearer picture, the percentage inhibition was plotted against the concentrations of Cystone and various extracts of Achillea millefolium Linn (figure 5). $\mathrm{IC}_{50}$ for each case were estimated by following the linear regression. The values of $\mathrm{IC}_{50}$, given in table 2, clearly indicate that the response of ethyl acetate extract of the plant is similar that of Cystone. In addition, there is a positive correlation between extracts and 


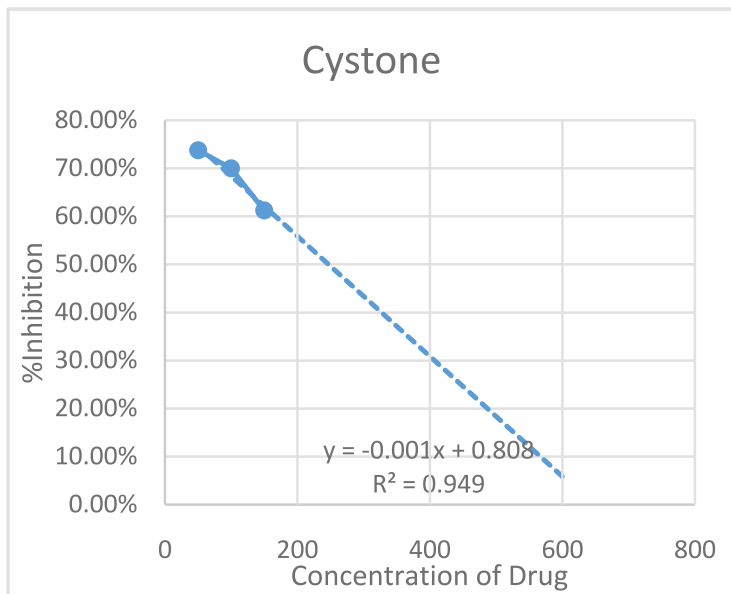

(a)

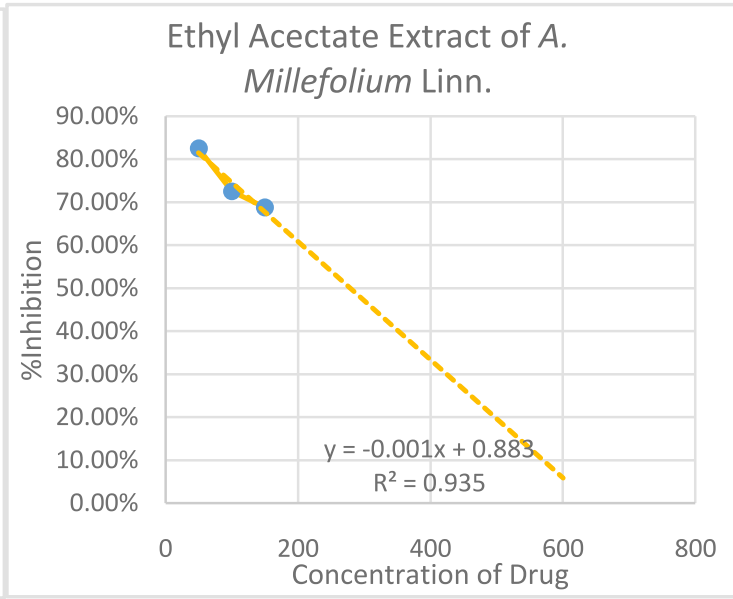

(b)

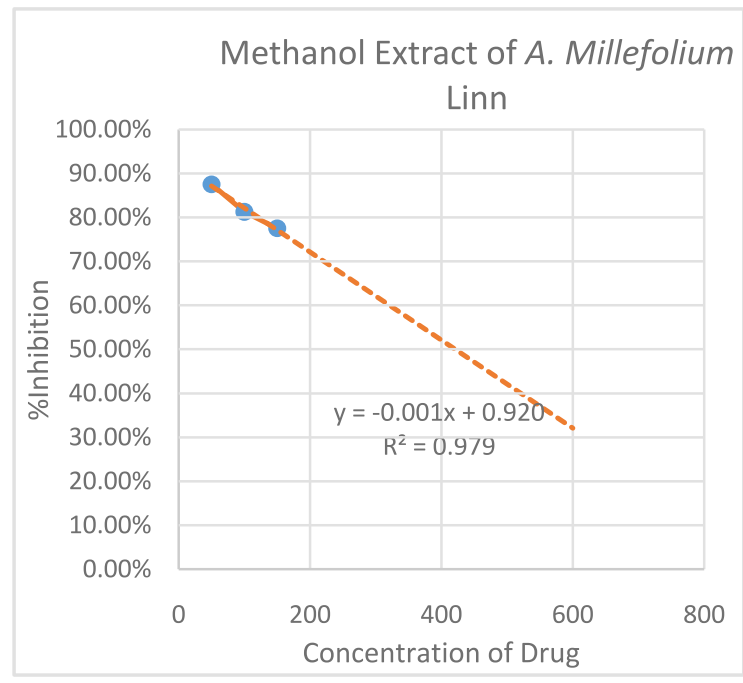

(c)

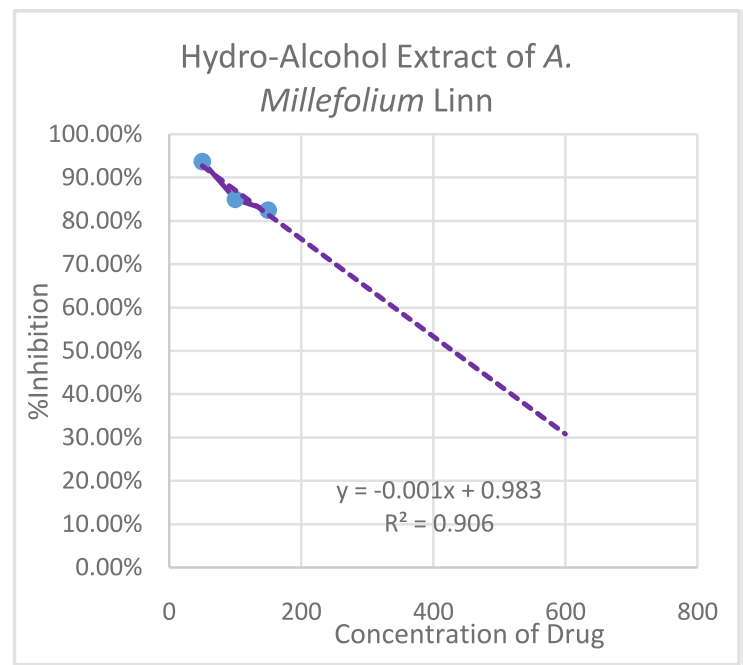

(e)

\section{Acetone Extract of A. Millefolium} Linn

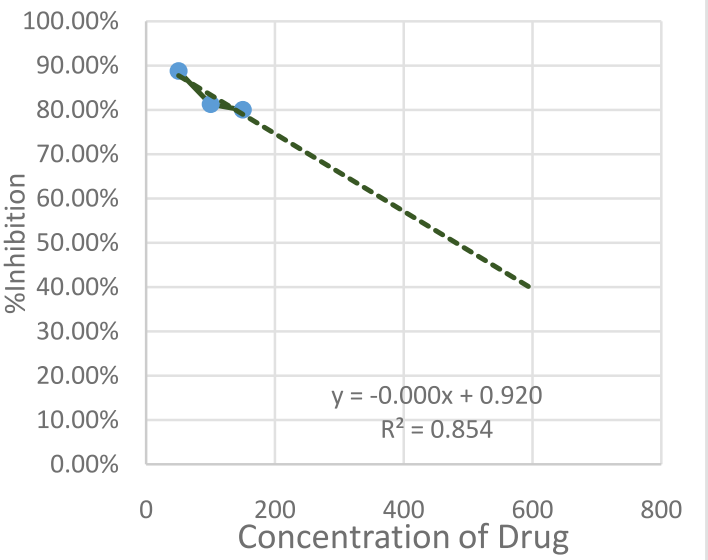

(d)

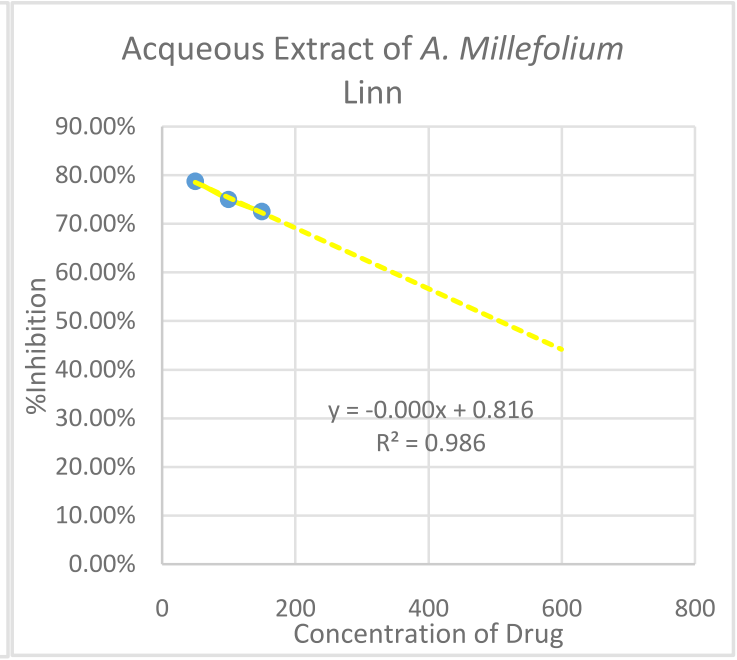

(f)

Fig. 4: Percentage inhibition of cystone and various extracts of A. millefolium Linn. 
the concentration used in the given study. More specifically, it means that if the concentration of extract increases percentage dissolution of calcium oxalate increases up to some limit, and hence the efficacy increases. Pertinent to mention here that the concentration is highly significant if pvalue $<0.01$ and significant if $p$-value is $<0.05$.

\section{CONCLUSION}

On the basis of the above findings it is concluded that, Achillea millefolium Linn. possesses lithotriptic action which increases with the increase in concentration of drug implying that the efficacy of the drug is directly proportional to the concentration of drug. This study serves the base for validation of the lithotriptic action of Baranjasif (Achillea millefolium Linn.). The Unani concept that the lithotriptic drug acts by means of Mufattit, Muhallil and Mufattih Sudad property of Baranjasif is also validated in this study. As this study is confined to in-vitro case, so both in-vivo and clinical trials should be carried out in future to further examine the lithotriptic activity of Baranjasif (Achillea millefolium Linn.) in a broader perspective. A rigorous study in future may include several trials with varying concentrations of extracts to carry out the extensive regression analysis to reach the precise results.

\section{DECLARATION OF INTEREST}

The authors report no conflicts of interest. The authors alone are responsible for the content and writing of this article.

\section{ACKNOWLEDGEMENTS}

The authors acknowledge the support and assistance provided by Prof. Zulfikar Ali Bhat, HoD Pharmaceutical science, Dr. Waqar, Assistant Professor Pharmacy University of Kashmir and Assistant Director, In charge, RRIUM Srinagar and Shabnam Bashir, PhD Scholar (Chemistry), Kashmir University, in this study.

\section{REFERENCES}

1. Divakar K, Pawar AT, Chandrasekhar SB, Dighe SB and Divakar G. Protective effect of the hydro-alcoholic extract of Rubia cordifolia roots against ethylene glycol induced urolithiais in rats. Food Chem Toxicol; 2010; 48: 1013-1018.

2. Bouanani S, Henchiri C, Migianu GE, Aouf $\mathbf{N}$ and Lecouve M. Pharmacological and toxicological effects of Paronychia argentea in experimental calcium oxalate nephrolithiasis in rats. J Ethnopharmacol, 2010; 129:38-45.

3. Barry M. The Kidney-Vol $2^{\text {nd }}, 8^{\text {th }}$ ed. Saunders Elsevier. Philadelphia 2008; pp 1299-1324.

4. John Axford. Medicine. Blackwell Science Ltd. Oxford 1996; 10.101-10.105.

5. Robert W, Carl W. Diseases of the Kidney-Vol 1, $6^{\text {th }}$ ed.
Little Brown and company. New York 1997: 739-747.

6. Krishna KVD. Textbook of Medicine. $5^{\text {th }}$ ed. Jaypee Brothers Medical Publishers. New Delhi 2008: 11371139.

7. Bigelow MW, Wiessner JH, Kleinman JG and Mandel GS. Calcium oxalate-crystal membrane interactions. J Urol 1982; 127: 152-4.

8. Orson W. Kidney stone. Pathophysiology and Medical Management. 2006; 367:333.

9. Basher S and Gilani, AH. Antiurolithiatic effect of Bergenialingulata rhizome: an explanation of the Underlying Mechanism. J. Ethnopharmacol 2009; 122, 106-116.

10. Pareta SK, Patra KC, Mazumder PM, Sasmal D. Establishing the principle of herbal therapy for antiurolithiatic activity: a review. J. Pharmacol. Toxicol 2011; 6: 321-332.

11. Goldfrank L. The pernicious Panacea: Herbal Medicine. Hospital Physician; 1982; 10:64-86.

12. Sina I. Al Qanoon Fit Tib, Vol. II and V (Urdu Trans: Idara Kitabus Shifa. New Delhi, 2007; pp 241-485; 4551569.

13. Nabi GM. Makhzan Mufradat waMurakabat (Khawasul Advia), $2^{\text {nd }}$ ed. Central Council for Research in Unani Medicine. New Delhi, 2007; pp 29-251; 305-28.

14. Kabeeruddin HM. Bayaz-i-Kabeer, Vol. II. Hikmat Book Depot, Hyderabad, 1938; pp 1-179.

15. Baitar IAK. Al Jami Li Mufradat Al Advia wal Aghzia, Vol. I-IV (Urdu). Central Council for Research in Unani Medicine. New Delhi, 1999; 1-450, 1-370, 19-394,121213, 21-463.

16. Trease GE and Evans WC. Pharmacognosy. $4^{\text {th }}$ ed. Bailliere Tindall. London 1972. pp 283.

17. Anne O, Elmer A, and Ain R. Phytochemical analysis of the essential oil of Achillea millefolium L. from various European countries. Nat Prod Res, 2006; 20: 1082-1088.

18. Kirtikar KR. and Basu BD. Indian Medicinal Plants, Vol. II. Lalit Mohan Publication, Allahabad, 2012; pp 1375-1378.

19. Ghani MN. Khazainul Advia (reprint). Idara Kitabus Shifa. New Delhi 2010; pp 166-1374.

20. Akram, M. Mini review on Achillea millefolium Linn. J Membrane Biol. 2013; 246, 661-663.

21. Khan MA. Muheet Azam, Vol I. Central Council for Research in Unani Medicine. New Delhi 1896. 
22. Usmanghani K, Saeed A, Tanweer A. Traditional uses of A. millefolium. Indus Med 1997; 1: 93-95

23. Karamenderes $\mathbf{C}$ and Apaydin S. Antispasmodic effect of Achillea nobilis L. subsp. Sipylea 8. (O. Schwarz) Bassler on the rat isolated duodenum. $J$ Ethnopharmacol. 2003; 84: 175-179.

24. Stojanovic G, Radulovic N, Hashimoto T, Palic R. In vitro antimicrobial activity of extracts of four Achillea species: the composition of Achillea clavennae L. (Asteraceae) extract. J Ethnopharmacol. 2005; 101: 185-190.

25. Cavalcanti A.M., Baggia C.H., Freita C.F. Safety and anti-ulcer efficacy study of Achillea millefolium L. After chronic treatment Wistar rats. J Ethnopharmocol; 2006; 107: 277-84.

26. Si XT, Zhang ML, Shi QW and Kiota $\mathbf{H}$. Chemical constituents of the plants in the genus Achillea. Chem Biodiverse 2006; 3: 1163-1118.

27. Tajik HO and Jalali SSF. In vitro assessment of antimicrobial efficacy of aqueous extract of garlic against wound-infecting microorganisms. Journal of Medicinal Plants. 2008; 2(26): 10-5.

28. Fierascu I, Ungureanu C, Avramescu SM, Fierascu RC, Ortan A, et al. In vitro antioxidant and antifungal properties of Achillea millefolium L. Rom Biotechnol Lett. 2015; 20: 10626-36.

29. Baser KH, Demirci B, Demirci F. Composition and antimicrobial activity of the essential oil of Achillea millefolium. planta med 2002; 68: 941-43
30. Benedek B, Rothwangi WK, Rozema E. Yarrow (Achillea millefolium); Pharmaceutical quality of commercial samples. Pharmazie 2008; 63: 23-26.

31. Jha R, Ramani PT, Patel D, Desai S, Meshram D. Phytochemical analysis and in vitro urolithiatic activity of Peltophorumpterocarpum (DC) Baker leaves. Journal of Medicinal Plant Studies. 2016; 4(3): 18-22

32. Saravanasingh K, Ramamurthy M, Parthiban P. In vitro anti-urolithiatic activity of aerial parts of Aervalanata (L.) Juss. Int J Curr Res Med Sci. 2016; 2(3):24-7.

33. Grases F and Conte A. Urolithiasis, inhibitors and promoters. Urological research. 1992; 20(1): 86-8.

34. Sathish R and Jayebalan G. Study of In Vitro AntiLithiatic Effect of Ipomoea Batatas (L) Leaves and Tuberous Roots. Asian Journal of Pharmaceutical and Clinical Research. 2018; 11(2): 427-431.

35. Liu Y, Chen Y, Liao B, Luo D, Wang $\mathbf{K}$, et al. Epidemiology of urolithiasis in Asia. Asian Journal of Urology. 2018; 5(4):205-14.

36. Ibn Zohr AMAM. Kitab Al-Taseer Fil Madawatwa AlTadbeer. $1^{\text {st }}$ ed. Urdu Trans: Central Council for Research in Unani Medicine. New Delhi, 1986; 153-157

37. Razi Z. Al-Hawi Fil Tib. $10^{\text {th }}$ edn. Urdu Trans: Central council for research in Unani Medicine. New Delhi, 2001; 92-93. 